\title{
The syndrome of Karl Ludwig Kahlbaum
}

\author{
MP BARNES, M SAUNDERS, TJ WALLS, I SAUNDERS, CA KIRK \\ From the Department of Neurology, Middlesbrough General Hospital, Middlesbrough, UK
}

SUMmARY Karl Ludwig Kahlbaum was the first to describe catatonia in 1868. There has been a tendency to consider catatonia as a psychiatric disease despite many case reports demonstrating a wide range of medical and neurological as well as psychiatric causes. We present our accumulated experience of the catatonic syndrome. Most cases (36\%) were associated with affective illness but five cases $(20 \%)$ had a defined organic disorder. A significant minority had no identifiable cause and there was only one case of schizophrenia. The idiopathic and affective groups had a high incidence of recurrent catatonic episodes and many had a family history of a similar problem. The prognosis was excellent, except for the few patients who presented with the acute and rapidly progressive form of the syndrome which led to acute renal failure.

Karl Ludwig Kahlbaum first described catatonia during a lecture in Innsbruck in 1868 and published his work on the subject 6 years later in a small monograph entitled "Die Katatonie oder das Spannungsirresein". ${ }^{2}$ He stressed that catatonia is strongly associated with affective illness, both depression and mania. He also gave examples of other diseases that are associated with catatonia; alcoholism, epilepsy, malaria, syphilis and tuberculosis. Although some of his cases eventually became "demented", he stressed that catatonia should not always be seen as a degenerating mental condition but in many cases there was a good prognosis for recovery. However, in 1893 Emil Kraepelin incorporated catatonia as a subtype of dementia praecox ${ }^{3}$ which was later termed schizophrenia by Eugene Bleuler. ${ }^{4}$ The work of Kraepelin and Bleuler has had much influence in the field of psychiatry and consequently there has been a tendency to consider catatonia as a purely psychiatric condition commonly associated with schizophrenia. In recent years there have appeared many reports of an association between catatonia and a wide variety of medical, neurological and psychiatric conditions. ${ }^{5}$

The aim of this paper is to present our experience of catatonia in a neurological unit over a 12 year period. Some of our cases illustrate new features of the catatonic syndrome.

Address for reprint requests: $\operatorname{Dr} M$ Saunders. Department of Neurology. Middlesbrough General Hospital, Ayresome Green Lane. Middlesbrough, Cleveland, TS5 5AZ, UK

Received 22 March 1985 and in revised form 30 January 1986. Accepted 3 February 1986

\section{Case reports}

A total of 25 cases of catatonia have been seen by the Department of Neurology at Middlesbrough General Hospital during the period 1972 to 1984 . The series may underrepresent cases with a psychiatric cause although we believe that most instances of catatonia have been referred to the Department because of the known interest of one of us (MS) in the disorder. Our minimum definition of catatonia is that the patient must have exhibited at least one motor sign (catalepsy, posturing or waxy flexibility) in combination with at least one sign of psycho-social withdrawal or excitement and/or bizarre repetitious movements (mutism, negativism, impulsiveness, grimacing, stereotypies, mannerisms, command automatism, echopraxia/echolalia or verbigeration). Most patients were also stuporose on presentation although we do not consider that stupor is a necessary prerequisite for the diagnosis of catatonia. Every patient had been seen by a neurologist (MS) and also by a consultant psychiatrist. Every effort has been made to make either a psychiatric or organic diagnosis. Investigations have included CT scanning, EEG, examination of cerebro-spinal fluid and appropriate screening tests for the known metabolic and systemic causes of the syndrome. ${ }^{5}$

In 15 cases we have defined the likely cause of the syndrome. Nine patients $(36 \%)$ had an affective illness. Five patients $(20 \%)$ had a probable organic cause and in one case $(4 \%)$ the patient was found to have schizophrenia. In 10 cases $(40 \%)$ no organic nor psychiatric cause could be determined despite intensive investigation.

\section{Psychiatric causes}

Table 1 summarises the cases associated with a defined psychiatric condition. The single case of catatonia associated with previously known schizophrenia was in a 26-year-old male. The catatonic episode responded to electroconvulsive therapy (ECT) but the long-standing schizophreniform illness continued unchanged. In the other nine cases catatonia 
Table 1 Psychiatric causes

\begin{tabular}{|c|c|c|c|c|}
\hline Patient & Sex & $\begin{array}{l}\text { Age at onset } \\
\text { of catatonia } \\
(y r)\end{array}$ & Diagnosis & $\begin{array}{l}\text { Number of } \\
\text { catatonic } \\
\text { episodes }\end{array}$ \\
\hline $1 \mathrm{MT}$ & $\mathbf{M}$ & 26 & Chronic schizophrenia & 1 \\
\hline $2 \mathrm{WC}$ & $\mathbf{M}$ & 60 & $\begin{array}{l}\text { Recurrent catatonia } \\
\text { associated with } \\
\text { depression }\end{array}$ & 3 \\
\hline $3 \mathrm{GC}$ & $\mathbf{M}$ & 63 & $\begin{array}{l}\text { Acute catatonia } \\
\text { associated with } \\
\text { depression }\end{array}$ & 1 \\
\hline $4 \mathrm{ML}$ & $\mathbf{F}$ & 21 & $\begin{array}{l}\text { Recurrent catatonia } \\
\text { associated with } \\
\text { depression }\end{array}$ & 3 \\
\hline 5 FS & $\mathbf{F}$ & 25 & $\begin{array}{l}\text { Recurrent catatonia } \\
\text { associated with } \\
\text { depression }\end{array}$ & 6 \\
\hline $6 \mathrm{DF}$ & $\mathbf{F}$ & 17 & $\begin{array}{l}\text { Recurrent catatonia } \\
\text { associated with } \\
\text { depression }\end{array}$ & 5 \\
\hline $7 \mathbf{H H}$ & $\mathbf{M}$ & 35 & $\begin{array}{l}\text { Recurrent catatonia } \\
\text { associated with } \\
\text { depression }\end{array}$ & 2 \\
\hline $8 \mathrm{DW}$ & $\mathbf{F}$ & 25 & $\begin{array}{l}\text { Recurrent catatonia } \\
\text { associated with } \\
\text { depression }\end{array}$ & $5 ? 6$ \\
\hline $9 \mathrm{VP}$ & $\mathbf{F}$ & 26 & $\begin{array}{l}\text { Acute catatonia secondary } \\
\text { to puerpueral depressive } \\
\text { illness }\end{array}$ & 1 \\
\hline $10 \mathrm{SS}$ & $\mathbf{F}$ & 13 & $\begin{array}{l}\text { Recurrent catatonia } \\
\text { associated with } \\
\text { depression }\end{array}$ & 2 \\
\hline
\end{tabular}

was associated with depression. Seven of the nine patients gave a family history of similar problems. Also seven of the patients had recurrent episodes of catatonia and on each occasion associated with the onset of a further period of depression. The two patients who only had a single catatonic illness both presented acutely to another hospital and one died from the effects of acute renal failure. A third patient also died in a psychiatric institute from acute renal failure during the sixth episode of catatonia. The patients who did not present with the acute and rapidly progressive form of the syndrome all had an excellent prognosis, making a full recovery either spontaneously or with ECT.

Family history Comments

Outcome

None

Twin brother (case 3 ) had one episode of acute catatonia

Twin brother of case 2

None

Aunt, sister and cousin (case 6) have had catatonia associated with depressive illness sister died from "acute lethal" catatonia

Cousin of case 5

Aunt (case 8) has similar problem. Sister had catatonia episode of uncertain cause Aunt of case ?

None

Grandfather, greatgrandfather and greatuncle all had similar condition
Catatonia responded to ECT but schizophrenic illness continues

Died by accidental drowning (not known to be depressed at the time)

Full recovery with ECT

Died

Also has generalised epilepsy

Episodes responded to ECT

5 episodes responded to ECT Died in acute, 6th episode from renal failure

Full recovery with ECT

Recovery with ECT

Recovery with ECT

Spontaneous recovery

Spontaneous recoveries $\stackrel{D}{D} \rightarrow$

Organic causes

Table 2 illustrates the five patients who were felt to have an organic cause for their catatonic illness. The precise cause in case 5 remains obscure although it is a reasonable assumption that there was some peri-operative interference, either mechanical or vascular, with brain stem or mid brain region. Four of the five cases suffered from short-lived catatonia of no real significance from the point of view of their neurological management and their recovery was complete and spontaneous. The exception to this was the patient who later developed clinically definite multiple sclerosis who made only a slow recovery with a combination of ECT and phenothiazine therapy.

Table 2

\begin{tabular}{|c|c|c|c|c|c|c|c|}
\hline Patient & $\operatorname{Sex}$ & $\begin{array}{l}\text { Age at onset } \\
\text { of catatonia } \\
(y r)\end{array}$ & Diagnosis & $\begin{array}{l}\text { Number of } \\
\text { catatonic } \\
\text { episodes }\end{array}$ & Family history & Comments & Outcome \\
\hline $\begin{array}{l}1 \mathrm{JK} \\
2 \mathrm{PL} \\
3 \mathrm{SP} \\
4 \mathrm{JE}\end{array}$ & $\begin{array}{l}\mathbf{F} \\
\mathbf{F} \\
\mathbf{F}\end{array}$ & $\begin{array}{l}22 \\
20 \\
20 \\
29\end{array}$ & $\begin{array}{l}\text { Encephalitis } \\
\text { Encephalitis } \\
\text { Tuberculous meningitis } \\
\text { Multiple sclerosis }\end{array}$ & $\begin{array}{l}1 \\
1 \\
1 \\
2\end{array}$ & $\begin{array}{l}\text { None } \\
\text { None } \\
\text { None } \\
\text { None }\end{array}$ & $\begin{array}{l}2 \text { episodes of catatonia } \\
\text { as first manifestations } \\
\text { of clinically definite } \\
\text { multiple sclerosis }\end{array}$ & $\begin{array}{l}\text { Spontaneous recovery } \\
\text { Spontaneous recovery } \\
\text { Spontaneous recovery } \\
\text { Slow recovery with ECT } \\
\text { and phenothiazines }\end{array}$ \\
\hline 5 AP & $\mathbf{M}$ & 24 & Post-operative catatonia & 1 & None & $\begin{array}{l}\text { Catatonia occurred post- } \\
\text { operatively after } \\
\text { removal of cerebellar } \\
\text { haemangioblastoma }\end{array}$ & Spontaneous recovery \\
\hline
\end{tabular}


Table 3 Idiopathic cases

\begin{tabular}{|c|c|c|c|c|c|c|c|}
\hline Patient & $\operatorname{Sex}$ & $\begin{array}{l}\text { Age at onset } \\
\text { of catatonia } \\
(y r)\end{array}$ & Diagnosis & $\begin{array}{l}\text { Number of } \\
\text { catatonic } \\
\text { episodes }\end{array}$ & Family history & Comments & Outcome \\
\hline $1 \mathrm{JA}$ & $\mathbf{F}$ & 39 & $\begin{array}{l}\text { Idiopathic familial } \\
\text { catatonia }\end{array}$ & 2 & $\begin{array}{l}\text { Son and daughter (cases } \\
2 \text { \&3) have same } \\
\text { condition }\end{array}$ & & $\begin{array}{l}\text { Slow improvement with } \\
\text { chlorpromazine (ECT } \\
\text { not used) }\end{array}$ \\
\hline $2 \mathrm{DA}$ & $\mathbf{M}$ & 19 & $\begin{array}{l}\text { Idiopathic familial } \\
\text { catatonia }\end{array}$ & 1 & $\begin{array}{l}\text { Mother (case 1) \& sister } \\
\text { (case 3) }\end{array}$ & $\begin{array}{l}\text { In cases } 2 \text { and } 3 \text { the } \\
\text { catatonia was associated } \\
\text { with occasional } \\
\text { generalised tonic/clonic } \\
\text { convulsions. Seizure } \\
\text { activity responded to } \\
\text { anticonvulsant therapy } \\
\text { but not the catatonia }\end{array}$ & $\begin{array}{l}\text { Recovered after } 4 \text { ECT } \\
\text { sessions over } 10 \text { days }\end{array}$ \\
\hline 3 LA & $\mathbf{F}$ & 11 & $\begin{array}{l}\text { Idiopathic familial } \\
\text { catatonia }\end{array}$ & 1 & $\begin{array}{l}\text { Mother (case 1) \& } \\
\text { brother (case 2) }\end{array}$ & & $\begin{array}{l}\text { Recovered after } 10 \text { ECT } \\
\text { sessions }\end{array}$ \\
\hline $4 \mathrm{KW}$ & $\mathbf{F}$ & 24 & Idiopathic catatonia & 3 & None & $\begin{array}{l}\text { Has generalised epilepsy. } \\
\text { One catatonic episode } \\
\text { followed a generalised } \\
\text { seizure during pregnancy }\end{array}$ & $\begin{array}{l}\text { All episodes responsive to } \\
\text { ECT }\end{array}$ \\
\hline $5 \mathrm{JS}$ & $\mathbf{F}$ & 25 & Idiopathic catatonia & 1 & None & $\begin{array}{l}\text { Has generalised epilepsy. } \\
\text { Dialysed whilst } \\
\text { catatonic because of } \\
\text { acute renal failure but } \\
\text { made complete recovery }\end{array}$ & $\begin{array}{l}\text { Catatonia responded to } \\
\text { ECT }\end{array}$ \\
\hline $6 \mathrm{GS}$ & $\mathbf{F}$ & 37 & $\begin{array}{l}\text { Idiopathic/recurrent } \\
\text { catatonia familial }\end{array}$ & 8 & $\begin{array}{l}\text { Daughter (case 7) and } \\
\text { brother had similar } \\
\text { problem }\end{array}$ & & $\begin{array}{l}\text { Episodes responded to } \\
\text { ECT }\end{array}$ \\
\hline $7 \mathrm{CS}$ & $\mathbf{F}$ & 20 & $\begin{array}{l}\text { Idiopathic/recurrent } \\
\text { catatonia familial }\end{array}$ & 6 & Mother (case 6) and uncle & & Spontaneous recoveries \\
\hline $8 \mathrm{EJ}$ & $\mathbf{F}$ & 42 & $\begin{array}{l}\text { Idiopathic/recurrent } \\
\text { catatonia }\end{array}$ & 3 & $\begin{array}{l}\text { Brother died from } \\
\text { "acute lethal" } \\
\text { catatonia }\end{array}$ & & Spontaneous recoveries \\
\hline 9 MP & $\mathbf{F}$ & 41 & $\begin{array}{l}\text { Idiopathic recurrent } \\
\text { catatonia }\end{array}$ & 8 & None & & Spontaneous recoveries \\
\hline $10 \mathrm{LS}$ & $\mathbf{F}$ & 51 & Idiopathic acute & 1 & None & & Died in acute renal failure \\
\hline
\end{tabular}

Idiopathic cases

Table 3 illustrates the 10 patients in whom no organic nor psychiatric cause could be determined. It is of interest that there was a marked familial tendency to develop catatonia among this group of patients, six of whom gave a family history of a similar disorder. In four cases the patient suffered from both generalised epilepsy and a recurrent catatonia and in case 4 a fit appeared to trigger one of the catatonic episodes. In cases 2 and 3 the catatonia was associated with occasional generalised tonic/clonic convulsions. The seizure activity responded to anticonvulsant medication but the catatonia only responded to ECT. Once again the acute and rapidly progressing form of the syndrome carried a poor prognosis and one of the two patients who had this presentation died in a psychiatric hospital from acute renal failure whilst the other recovered following dialysis. The remainder of the group had an excellent prognosis, either recovering spontaneously or following ECT. Nine of the 10 cases in this group were female.

\section{Discussion}

Our series has emphasised that catatonia is a nonspecific entity that has a wide range of organic and psychiatric causes. There has been undue emphasis on the association with schizophrenia which in our experience is an unusual cause. The commonest defined association is affective illness but full neu- rological and general medical investigation remains necessary to exclude the organic diseases that can underlie the syndrome. Gelenberg ${ }^{5}$ listed many of the causes that had been reported up to 1976 but more recently several more associations have been published. We have reviewed the current literature and Table 4 lists the known causes of the syndrome at the present time.

Our series illustrates that despite full investigation there remains a significant minority of patients who have no defined organic or psychiatric disease. We wish to.draw attention to this interesting group of patients. We are not aware of any previous series that has shown such a definite familial tendency to recurrent episodes of catatonia. It is also of interest that four of this group had generalised epilepsy, both during catatonic periods and during periods of normal behaviour. Although this association was described by Kahlbaum in his original monograph ${ }^{12}$ it has received scant attention in the modern literature. Thompson and Greenhouse ${ }^{43}$ described three cases of catatonia occurring during "petit mal status". $\mathrm{Kramer}^{44}$ proposed epilepsy in a case of menstrually related catatonic stupor which eventually responded to phenytoin. Shah and Kaplan ${ }^{45}$ illustrated an episode of catatonia in a 10-year-old girl whose EEG 
Table 4 Causes of catatonia

1. Metabolic disorders-Diabetic keto-acidosis 6

- Homocystinuria?

- Hypercalcaemia ${ }^{8}$

-Acute intermittent porphyria 9

2. Systemic Disorders-Hepatic failure
- Renal failure ${ }^{12}$

- Hereditary coproporphyria ${ }^{10}$

3. Toxic agents and drugs

-Central Neryous System Depressants:-alcohol; ${ }^{13}$ anticonvulsants; ${ }^{14}$ disulphuram; ${ }^{15}$ glutethamide withdrawal; ${ }^{16}$ morphine; ${ }^{17}$ neuroleptics. ${ }^{18-20}$

-Central Nervous System Stimulants:-amphetamines/cannabis; ${ }^{21}$ mescalin; ${ }^{22}$ methyl phenidate; ${ }^{23}$ phenylcyclidine. ${ }^{5}$

- Other Drugs or Toxic Agents: - aspirin; ${ }^{24}$ levodopa; ${ }^{25}$ fluorinated hydrocarbons; ${ }^{26}$ coal gas; ${ }^{24}$ steroids. ${ }^{27}$

4. Neurological Disorders

Cerebrovascular Disease:-subarachnoid haemorrhage $;^{28-30}$ cerebral infarct; ${ }^{31}{ }^{32}$ cortical venous thrombosis; ${ }^{33}$ thrombotic thrombocytopenic purpora. ${ }^{34}$

- Cerebral Tumours:- various sites. ${ }^{35-39}$

-Degenerative conditions Kraepelin's dementia; ${ }^{40}$ Parkinsonism. ${ }^{41-42}$

-Epilepsy. ${ }^{43-43}$

-Neurological Infections:- chicken pox; ${ }^{46}$ encephalitis lethargica; ${ }^{47}$ herpes encephalitis; ${ }^{48}$ hydatid disease; $;{ }^{49}$ malaria; ${ }^{50}$ post

immunisation encephalopathy; ${ }^{51}$ subacute sclerosing panencephalitiss; $; 2$ syphilis; $;^{24}$ tuberculosis; $^{12}$ typhoid. $^{53}$

- Neurological Trauma:- post head injury; ${ }^{44}$ subdural haematoma. ${ }^{53}$

- Other Neurological Lesions:- Cerebral lupus erythematosus; ${ }^{56}$ frontal lobe atrophy; ${ }^{57}$ hydrocephalus; ${ }^{58}$ multiple sclerosis; ${ }^{59}$

narcolepsy; ${ }^{60}$ tuberose sclerosis ${ }^{61}$

5. Psychiatric Disorders:- - schizophrenia; ${ }^{34}$ affective illness; 626364 dissociative states ${ }^{5}$

showed "high voltage bursts of sharp waves, spikes, polyspikes and diffuse slowing bilaterally". She responded dramatically to intravenous phenytoin. In one of our patients the catatonia appeared to be triggered by a generalised convulsion but in no case did treatment of the epilepsy affect the catatonic state.

A familial tendency to catatonia is also apparent in patients who have a depressive illness. We are not aware of any similar description in the literature. These families appear to have recurrent, but irregular, periods of depression each associated with catatonia. These people differ from those with "periodic catatonia" as described by Rolv Gjessing 22 in that his patients had a more regular and predictable pattern of recurrence without any family history.

In our organic group the association with tuberculous meningitis is most unusual and this appears to be the first definite case described. Kahlbaum ${ }^{12}$ does mention tuberculosis in some of his cases but this may have been a secondary phenomenon due to long periods of debilitation. Multiple sclerosis also appears to be a rare cause of catatonia. The only other report ${ }^{59}$ is that of a 29 year old woman who presented withdrawn, retarded and cataleptic and who later developed symptoms and signs diagnostic of multiple sclerosis.

In terms of prognosis our patients appear to divide into 2 groups. The 4 patients who presented with an acute and rapidly progressive form of catatonia had a high mortality and 3 of them died in acute renal failure. This acute form of the illness, often associated with the name of Stauder ${ }^{66}$ and termed acute lethal catatonia, requires intensive treatment, particularly correction of dehydration, maintenance of renal function, withdrawal of neuroleptics, prevention of respi- ratory and cardiovascular complications and cooling to prevent death from hyperthermia. ${ }^{67}$ There is a degree of clinical overlap between acute lethal catatonia and the neuroleptic malignant syndrome which was originally described by Delay and Deniker. ${ }^{68}$ This syndrome represents an idiosyncratic response to antipsychotic agents particularly the butryophenones and phenothiazines. It is usually characterised by akinesia, rigidity, hyperthermia, autonomic instability and often stupor and coma. Other catatonic features can be found in the early stages. The pathogenesis is thought to be related to dopamine receptor blockade. ${ }^{69}$ Successful treatment of the syndrome with levodopa/carbidopa or bromocriptine in combination with dantrolene ${ }^{67} 70$ gives rise to optimism for the treatment of acute lethal catatonia. If the acute illness is treated quickly then the long term prognosis ought to be good and no patient ought to succumb to the effects of acute renal failure.

The patients who did not present acutely all had an excellent outcome with the exception of a single patient with schizophrenia. In most cases the recovery was spontaneous or occurred after a course of ECT. Our patients tended to improve after a single shock and usually only required four to six shocks over a 1 to 2 week period to come completely out of the catatonia. We would agree with Waziri ${ }^{65}$ that ECT is the "safest and most effective treatment in the majority of catatonic states." ECT need not be restricted to the affective or idiopathic groups but can be used when an organic cause is found for the syndrome. Breakey and $\mathrm{Kala}^{53}$ found that all 12 patients with typhoid catatonia made a rapid recovery with ECT, requiring only three or four sessions for remission. We would also recommend that ECT be used in the treatment of 
acute lethal catatonia. Although we have no personal experience of the use of ECT in this variety of catatonia we see no reason why recovery should not be as rapid as in the less acute condition. Rapid employment of ECT may reduce the mortality and morbidity at present associated with acute catatonia.

The historical association of catatonia with chronic schizophrenia has often engendered a feeling of therapeutic nihilism. Perhaps a new name for the syndrome will act as a reminder that there are many treatable causes. We suggest that catatonia be known as Kahlbaum's syndrome to honour the man who so accurately described the disorder over a century ago.

\section{References}

${ }^{1}$ Kahlbaum KL. Die katatonie oder das spannungsirresein. Berlin, Klinische Abhandlungen uber psychische Krankheiten, 1874.

${ }^{2}$ Kahlbaum KL. Catatonia. Baltimore, Johns Hopkins University Press, 1973.

${ }^{3}$ Kraepelin E. Dementia Praecox and Paraphrenia. (Translated by Barclay RM), Huntington, New York, Robert E Krieger, 1971 (Fascimile 1919 Ed.)

${ }^{4}$ Bleuler E. Dementia Praecox or the Group of schizophrenias, (Translated by Zinkin J), New York, International Universities Press, 1950.

${ }^{5}$ Gelenberg AJ. The catatonic syndrome. Lancet 1976;i: 1339-41.

${ }^{6} \mathrm{Katz}$ SE. A catatonic syndrome associated with diabetes mellitus. Arch Neurol Psychiatr 1934;31:880-1.

${ }^{7}$ Freeman JM, Finkelstein JD, Mudd SH. Folate responsive homocystinuria and 'schizophrenia'. $N$ Engl J Med 1975;292:491-6.

${ }^{8}$ Cooper AF, Schapira K. Case report: depression, catatonic stupor and EEG changes in hyperparathyroidism. Psychol Med 1973;3:509-15.

${ }^{9}$ Freeman JG, Kolb LC. Acute intermittent porphyria: associated psychiatric symptoms treated by electroshock. Proc Mayo Clinic 1951;26:401-5.

${ }^{10}$ Offenstadt G, Bienvenu MP, Hericord PH, Tawill S, Amstutz PH. Catatonia grave, schizophrenie et coproporphyrie hereditaire. Sem Hosp 1980;56 1727-30.

${ }^{11} \mathrm{Jaffe}$ N. Catatonia and hepatic dysfunction. Dis Nerv Syst 1967;8:606-8.

${ }^{12}$ Steinmann TI, Yagar HM. Catatonia in uremia. Ann Intern Med 1978;89:74-5.

${ }^{13}$ Bender L, Schilder P. Encephalopathia alcoholica. Arch Neurol Psychiatr 1933;29:990-1053.

${ }^{14}$ Sher A, Andersen JM, Bhatia SC. Primidone-induced catatonic schizophrenia. Drug Intell Clin Pharm 1983;17:551-2.

${ }^{15}$ Weddington WW, Marks RC, Verghese JP. Disulfiram encephalopathy as a cause of the catatonic syndrome. Am J Psychiatry 1980;137:1217-9.

${ }^{16}$ Good MI. Catatonia-like symptomatology and withdrawal dyskinesias. Am J Psychiatry 1976;133:1454-6.

${ }^{17}$ Enquist A, Jorgensen BC, Andersen HB. Catatonia after epidural morphine. Acta Anaesthesiol Scand 1981; 25:445-6.

${ }^{18}$ May RH. Catatonic-like states following phenothiazine therapy. Am J Psychiatry 1959;116:1119-20.

${ }^{19}$ Gelenberg AJ, Mandel MR. Catatonic reactions to highpotency neuroleptic drugs. Arch Gen Psychiatry 1977;34:947-50.

${ }^{20}$ Weinberger DR, Kelly MJ. Catatonia and malignant syndrome. A possible complication of neuroleptic administration. J Nerv Ment Dis 1977;165:263-8.

${ }^{21}$ Warner AM, Peirozynski G. Pseudocatatonia associated with abuse of amphetamine and cannabis. Postgrad Med 1977;61:275-7.

${ }^{22}$ Gjessing RR. Contribution to the Somatology of Periodic Catatonia. Oxford, Pergamon Press, 1976.

${ }^{23}$ Janowsky DS, El-Yousef MK, Davis JM, Sekerke HJ. Provocation of schizophrenic symptoms by intravenous administration of methylphenidate. Arch Gen Psychiatry 1973;28:185-91.

${ }^{24}$ Herman M, Harpham D, Rosenblum M. Nonschizophrenic catatonic states. N Y State J Med 1942;42:624-7.

${ }^{25}$ Barbeau A. Dopamine and mental function In: Malitz S, ed. L-Dopa and Behaviour. New York, Raven Press 1972:9-31.

${ }^{26}$ Schwab JJ, Barrow MV. A reaction to organic fluorides simulating classical catatonia. Am J Psychiatry 1964;120:1196-7.

${ }^{27}$ Sullivan BJ, Dickerman JD. Steroid associated catatonia: report of a case. Pediatrics 1979;63:677-9.

${ }^{28}$ Hanson GD, Brown MJ. Waxy flexibility in a postpartum woman. Psychiatr $Q$ 1973;47:95-103.

${ }^{29}$ Thompson GN. Cerebral lesions simulating catatonia; three case reports. Biol Psychiatry 1970;2:59-64.

${ }^{30}$ Solomon JG. Distinguishing catatonia: A case report. Psychosomatics 1978;19:299-307.

${ }^{31}$ Tippin J, Dunner FJ. Bi-parietal infarctions in a patient with catatonia. Am J Psychiatry 1981;138:1386-7.

${ }^{32}$ Malamud N, Boyd DA. Sudden brain death in schizophrenia with extensive lesions in the cerebral cortex. Arch Neurol Psych 1929;41:352-64.

${ }^{33}$ Gangadhar BN, Keshavan MS, Goswani U, Vasuder Rao T. Cortical venous thrombosis presenting as catatonia. A clinicopathological report. J Clin Psychiatry 1983; 44:109-10.

${ }^{34}$ Read SL. Catatonia in thrombotic thrombocytopenic purpura. J Clin Psychol 1984;44:343-4.

${ }^{35}$ Furtado D, Freitas A. Catatonie par compression diencephalique. Rev Neurol (Paris) 1946;78:499-500.

${ }^{36} \mathrm{De}$ Morsier G. Trois cas de tumeur du septum developpes dans le ventricule lateral, avec troubles du comportement. Encephale 1968;57:181-93.

${ }^{37}$ Steriade M, Botez MI, Petrovici I. On certain dissociations of consciousness levels with the syndrome of akynetic mutism. Psychiatria Neurologia 1961;141: 38-58.

${ }^{38}$ Malamud N. Psychiatric disorder with intracranial tumours of the limbic system. Arch Neurol 1967; 17:113-23.

${ }^{39}$ Newmann MA. Periventricular diffuse pinealome. J Nerv Ment Dis 1955;121:193-204.

${ }^{40}$ Schaumburg HH, Suzuki K. Non-specific familial pre- 
senile dementia. J Neurol Neurosurg Psychiatry 1968;31:479-86.

${ }^{41}$ Brain R. Diseases of the Nervous System, London, Clarendon Press, 1962.

${ }^{42}$ Mettler FA. Perceptual capacity, function of the corpus striatum and schizophrenia. Psychiatr $Q$ 1955; 29:89-111.

${ }^{43}$ Thompson SW, Greenhouse AH. Petit mal status in adults. Ann Intern Med 1968;68:1271-9.

${ }^{44} \mathrm{Kramer}$ MS. Menstrual epileptoid psychosis in an adolescent girl. Am J Dis Child 1977;131:316-7.

${ }^{45}$ Shah P, Kaplan SL. Catatonic symptoms in a child with epilepsy. Am J Psychiatry 1980;137:738-9.

${ }^{46}$ Blau A, Averbuck SH. Catalepsy or cerea flexibilitas in a 3 year old child. Am J Psychiatry 1936;92:967-77.

${ }^{47}$ Tilney F, Howe HS. Epidemic Encephalitis. New York, Paul B Hoebner, 1920.

${ }^{48}$ Raskin DE, Frank SW. Herpes encephalitis with catatonic stupor. Arch Gen Psychiatry 1974;31:544-6.

${ }^{49}$ Brage D, Pedace EA, Napolitano AG. Estupor hipotalimico por hidatide diencefalohipofisaria. Prensa Med Arg 1956;43:2954-9.

${ }^{50}$ Durrant W. Catatonia after malaria. $\mathrm{Br} \mathrm{Med} J$ 1977;2:893.

${ }^{51} \mathrm{Kim} \mathrm{CH}$, Perlstein MA. Encephalitis with catatonic schizophrenic symptoms. IMJ 1970;138:503-7.

${ }^{52}$ Koehler K, Jakumeit U. Sub-acute sclerosing panencephalitis presenting as Leonhard's Speech-prompt Catatonia. Br J Psychiatry 1976;129:29-31.

${ }^{53}$ Breakey WR, Kala AK. Typhoid catatonia responsive to ECT. Br Med J 1977;2:357-9.

${ }^{54}$ Sutter JM, Bardenat C, Pheline C, Coudray J-P. La catatonie posttraumatique ses rapports avec les 'etats de decerebration' et les 'comas prolonges'. Rev Neurol (Paris) 1959;101:524-35.

${ }^{55}$ Woods SW. Catatonia in a patient with sub-dural haematomas. Am J Psychiatry 1980;137:983-4.

${ }^{56} \mathrm{Kronfol} Z$, Schlesser M, Tsuang MT. Catatonia and sys- temic lupus erythematosus. Dis Nerv Syst 1977; 38:729-31.

${ }^{57}$ Ruff RL, Russakoff LM. Catatonia with frontal lobe atrophy. J Neurol Neurosurg Psychiatry 1980;43:185-7.

${ }^{58}$ Foltz EL, Ward AA. Communicating hydrocephalus from sub-arachnoid bleeding. $J$ Neurosurg 1956; 13:546-66.

${ }^{59}$ Mathews WB. Multiple sclerosis presenting with acute remitting psychiatric symptoms. J Neurol Neurosurg Psychiatry 1979;42:859-63.

${ }^{60}$ Cave HA. Narcolepsy. Arch Neurol Psych 1931; 26:50-101.

${ }^{61}$ Critchley M, Earl CJC. Tuberose sclerosis and allied conditions. Brain 1932;55:311-46.

${ }^{62}$ Abrams R, Taylor MA. Catatonia: a prospective clinical study. Arch Gen Psychiatry 1976;33:579-81.

${ }^{63}$ Taylor MA, Abrams R. The phenomenology of mania: a new look at some old patients. Arch Gen Psychiatry 1973;29:520-2.

${ }^{64}$ Taylor MA, Abrams R. Catatonia: prevalence and importance in the manic phase of manic-depressive illness. Arch Gen Psych 1977;34:1223-5.

${ }^{65}$ Waziri R. Catatonia. JAMA 1977;238:2495.

${ }^{66}$ Stauder KH. Die todliche katatonie. Archiv fur psychiatrie und Nervenkrankheiten 1934;102:614-34.

${ }^{67}$ Anon. Neuroleptic Malignant Syndrome. Lancet 1984;i: 545-6.

${ }^{68}$ Delay J, Deniker P. Drug-induced Extrapyramidal Syndromes. In: Vinken PJ, Bruyn GW, eds. Diseases of the Basal Ganglia. Handbook of Clinical Neurology, Vol 6, Amsterdam, North Holland Publishing Co 1968:258-9.

${ }^{69}$ Henderson VW, Wooten GF. Neuroleptic malignant syndrome: a pathogenetic role for dopamine receptor blockade? Neurology 1981;31:132-6.

${ }^{70}$ Granato JE, Stern BJ, Ringel A, et al. Neuroleptic malignant syndrome: successful treatment with dantrolene and bromocriptine. Ann Neurol 1983;14:89-90. 